\title{
Characterization of pTZ12, a Chloramphenicol-resistance Plasmid in Bacillus subtilis
}

\author{
Megumi Kono, Takashi Aoki, Masanori SaSatsu, \\ Norihisa Noguchi and Koji O'HaRA \\ Department of Microbiology, Tokyo College of Pharmacy, \\ 1432-1 Horinouchi, Hachioji, Tokyo 192-03, Japan
}

Received November 12, 1984

\begin{abstract}
The chloramphenicol-resistance $\left(\mathrm{CP}^{\mathrm{r}}\right)$ plasmid pTZ12 $(2.55 \mathrm{~kb})$ in Bacillus subtilis was genetically analyzed in detail, and the $\mathrm{CP}^{\mathrm{r}}$ determinant and the functional unit of replication were mapped. The plasmids pTZ12 and pBR322 were digested with suitable restriction endonucleases and ligated with T4 ligase. The ligated DNAs were introduced into $E$. coli by transformation and CP-resistant transformants were selected. In conclusion, the $\mathrm{CP}^{\mathrm{r}}$ determinant was mapped between a TaqI site and a BclI site (about 900 base pairs) on pTZ12. A set of pTZ12-pBR322 recombinant plasmids isolated from $E$. coli was introduced into $B$. subtilis by transformation to test for ability to replicate in $B$. subtilis. From the results, the region of the functional unit of pTZ12 replication was mapped. It was also proved that the gene product of this $\mathrm{CP}^{\mathrm{r}}$ determinant was chloramphenicol acetyltransferase (CAT) and the native CAT in the cells carrying pTZ12 was a dimeric protein with two identical subunits having a molecular weight of approximately $24,000(24 \mathrm{~K})$.
\end{abstract}

It has been reported that several antibiotic resistance plasmids originally detected in Staphylococci and Streptococci can be introduced into B. subtilis and are stably maintained and expressed in the new host. ${ }^{1 \sim 5)}$ These plasmids would become very useful cloning vectors in $B$. subtilis.

This laboratory has described a number of plasmid cloning vectors from $S$. aureus. ${ }^{2,6,7)}$ In a previous paper, ${ }^{8)}$ we reported $\mathrm{CP}^{\mathrm{r}}$ plasmid pTZ11 and its derivatives from Corynebacterium xerosis. Among these plasmids, $\mathrm{CP}^{\mathrm{r}}$ plasmid pTZ12 had a small molecular size of 2.55 kilobases $(\mathrm{kb})$, and produced chloramphenicol acetyltransferase (CAT) extracellularly. This paper deals with the genome characterization of the pTZ12, the mapping of the $\mathrm{CP}^{\mathrm{r}}$ determinant and the functional unit of the replication, and with the gene products of the $\mathrm{CP}^{\mathrm{r}}$ determinant, or CAT.

\section{MATERIALS AND METHODS}

Bacterial strains and plasmids. The strains used as recipients in transformation were $B$. subtilis RM125 $(\arg A 15, \text { leuA8, hsr M, hsmM })^{9)}$ and E. coli ML1410, which is a nalidixic acid-resistant mutant of $E$. coli $\mathrm{K} 12$. Strain $B$. subtilis BKS 2-2 is a derivative of $B$. subtilis RM125 that carries the $\mathrm{CP}^{\mathrm{r}}$ plasmid pTZ12. ${ }^{8}$ In our reports, "pTP" has been used as a plasmid name, but we took the advice of Dr. Lederberg of the Plasmid Reference Center and exchanged this plasmid name for "pTZ." The plasmids pTP11 and pTP12 in a previous paper ${ }^{8)}$ are named pTZ11 and pTZ12 in this paper.

Media and chemicals. For preparing plasmids from $B$. subtilis and $E$. coli, cells were grown in Trypto-soy broth (Eiken, Tokyo) or in L broth. ${ }^{10)}$ For other experiments, Penassay broth (Difco) and brain heart infusion (BHI) broth (Eiken, Tokyo) were used routinely for bacterial growth in liquid media. Heart infusion (HI) agar (Eiken, Tokyo) was used for agar plates. All antibiotics were purchased from the Sigma Chemical Company.

Plasmid DNA isolation. The procedures for the preparation of plasmid DNA from B. subtilis and E. coli were described by Tanaka et al. ${ }^{11)}$ and Birnboim et al., ${ }^{12)}$ respectively.

Transformation procedure. Protoplast cells of B. subtilis RM125 were transformed by the method of Chang and Cohen. ${ }^{13)}$ Competent cells of $E$. coli ML1410 were made according to the method of Mandel and Higa. ${ }^{14)}$ 


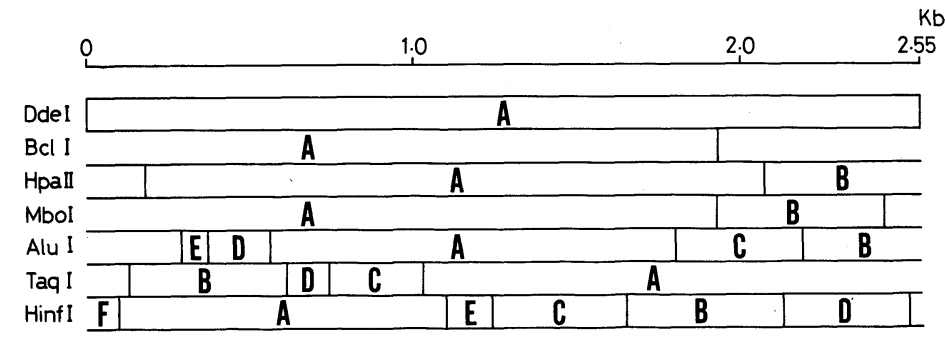

FIG. 1. Restriction Endonuclease Cleavage Map of pTZ12.

The unique $D d e I$ site is the point of reference. Distance from the DdeI site is shown in kb.

Transformants were selected using HI agar plates or DM3 plates containing $10 \mu \mathrm{g}$ of $\mathrm{CP}$ per $\mathrm{ml}$.

Construction and analysis of plasmids. Restriction endonucleases and T4 DNA ligase, purchased from New England Biolabs and Bethesda Research Laboratories, were used according to the manufacturer's instructions. Agarose gel electrophoresis was done to analyze the plasmids as described in our previous paper. ${ }^{8)}$

Assay of chloramphenicol acetyltransferase. Chloramphenicol acetyltransferase (CAT) activity was assayed by spectrophotometry. ${ }^{15)}$

Preparation of crude extract. An overnight culture of bacteria was inoculated into fresh BHI broth and shaken for about $3 \mathrm{hr}$ at $37^{\circ} \mathrm{C}$. The culture in exponential growth phase was centrifuged at $10,200 \times g$ for $20 \mathrm{~min}$. The broken cells obtained by sonic oscillation were centrifuged at $20,000 \times g$ for $30 \mathrm{~min}$, and the supernatant fluid were ultracentrifuged at $105,000 \times g$ for $2 \mathrm{hr}$. This supernatant fluid was used as a crude extract.

Partial purification of crude extract. A Sephadex G100 column $(1.9 \times 40 \mathrm{~cm})$ was equilibrated with $0.05 \mathrm{M}$ Tris- $\mathrm{HCl}$ buffer, $\mathrm{pH}$ 7.8. Crude extract was put on the Sephadex column and eluted with the same buffer at a flow rate of $12 \mathrm{ml} / \mathrm{hr}$. Fractions of $10 \mathrm{ml}$ were collected and each fraction was assayed for CAT activity. Two $\mathrm{ml}$ of the peak fraction showing the highest CAT activity was put on the same column again and eluted with the same buffer, and $1.5 \mathrm{ml}$ fractions were collected. Each fraction was assayed for the enzyme activity, and the protein concentration was estimated by ultraviolet absorption at $280 \mathrm{~nm}$. To examine the elution volume of protein markers, $2 \mathrm{ml}$ of $0.05 \mathrm{M}$ Tris- $\mathrm{HCl}$ buffer, $\mathrm{pH} 7.8$ containing BSA (68K), ovalbumin (44K), chymotrypsinogen $(25 \mathrm{~K})$, and cytochrome $c(13 \mathrm{~K})$ was put on the same column and eluted under the same conditions. The marker elution profiles were determined by absorbance at $280 \mathrm{~nm}$.

SDS polyacrylamide gel electrophoresis. Estimates of the molecular weights of the enzyme subunits were made in

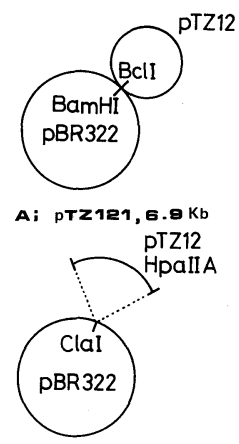

C; pTZ123, 6.2 Kb
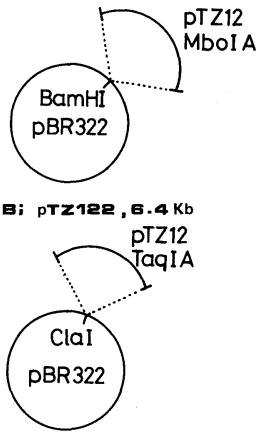

D) pтz124,6.0 Kb
FIG. 2. Construction of pTZ12-pBR322 Recombinant Plasmids.

(A) pTZ121, obtained by cloning the full-length pTZ12 digested with $\mathrm{Bcl}$ I into the unique BamHI site of pBR322; (B) pTZ122, obtained by cloning pTZ12 MboI fragment A into the unique BamHI site of pBR322; (C) pTZ123, obtained by cloning pTZ12 HpaII fragment A into the unique ClaI site of pBR322; (D) pTZ124, obtained by cloning pTZ12 TaqI fragment A into the unique ClaI site of $\mathrm{pBR} 322$.

the presence of $0.1 \%$ SDS in $14 \%$ polyacrylamide gel using the protein markers described above. Proteins were detected by staining with a silver stain kit (Ag-STAIN "DAIICHI," Daiichi Pure Chemicals Co., Ltd., Tokyo).

\section{RESULTS}

\section{Restriction endonuclease map of pTZ12}

A restriction endonuclease map of $\mathrm{CP}^{\mathrm{r}}$ plasmid pTZ12 was constructed (Fig. 1). The relative positions of restriction sites of the plasmid were determined from the molecular weights of DNA fragments produced by digestion with appropriate combinations of restriction endonucleases. 


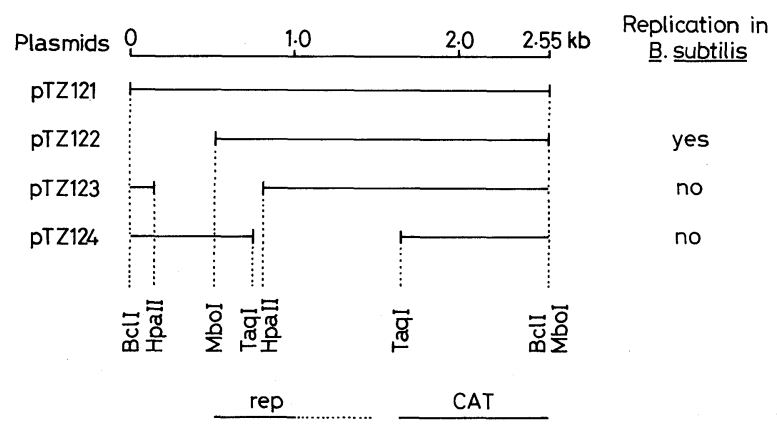

FIG. 3. Schematic Diagram Summarizing Properties of pTZ12-pBR322 Recombinant Plasmids.

Recombinant plasmids (pTZ121, pTZ122, pTZ123, and pTZ124) constructed by cloning pTZ12 DNA fragments into pBR322 expressed CP resistance in $E$. coli and these recombinant plasmids were tested for ability to replicate in $B$. subtilis.

\section{Map region of $C P^{\mathrm{r}}$ determinant on $p T Z 12$}

To determine the map region of the $\mathrm{CP}^{\mathrm{r}}$ determinant, recombinant plasmids constructed by insertion of the various pTZ12 DNA fragments into pBR322 were tested for ability to express $\mathrm{CP}$ resistance in E. coli. Plasmids pTZ12 and pBR322 were digested with $B c l$ I and BamHI, respectively, mixed, and ligated with T4 ligase. The recombinant plasmids thus obtained were used in a transformation experiment with E. coli ML1410 as the recipient. Transformants resistant to CP were selected and screened for resistance to ampicillin (ABPC). Plasmid DNA was isolated from one of the transformants resistant to $\mathrm{CP}$ and $\mathrm{ABPC}$, and characterized by restriction endonuclease digestion. This recombinant plasmid (pTZ121) contained full-length pTZ12 inserted into the unique BamHI site of pBR322 (Fig. 2A). Thus, it was proved that the $\mathrm{CP}^{\mathrm{r}}$ determinant on pTZ12 had the ability to express CP resistance in E. coli. Plasmids pTZ12 and pBR322 were then digested with $\mathrm{MboI}$ and BamHI, respectively, mixed, and ligated. The ligated DNA mixture was used for a transformation experiment with $E$. coli ML1410 as the recipient. CP- and ABPCresistant transformants were selected. Plasmid DNAs were isolated from these transformants and characterized by restriction endonuclease digestion. One recombinant plasmid (pTZ122) contained the larger $M b o I$ fragment $(\mathrm{A}, 2.0 \mathrm{~kb})$ from pTZ12 (Fig. 2B). The recombinant plas- mids pTZ123 and pTZ124 were also obtained by a similar experimental procedure. Plasmid pTZ123 was obtained by cloning the larger HpaII fragment (A, $1.85 \mathrm{~kb}$ ) of pTZ12 (Fig. 2C). Plasmid pTZ124 was obtained by cloning the largest $T a q \mathrm{I}$ fragment $(\mathrm{A}, 1.65 \mathrm{~kb})$ of pTZ12 (Fig. 2D). In E. coli, these recombinant plasmids specified resistance to at least $25 \mu \mathrm{g}$ of CP per ml. Plasmid pTZ12 DNA portions of each recombinant plasmid are shown in Fig. 3. From the data, it was proved that the $\mathrm{CP}^{\mathrm{r}}$ determinant could be mapped between the TaqI site and the BclI site (about 900 base pairs) on pTZ12 (Fig. 3).

\section{Map region of replication function of pTZ12}

To define the functional unit of pTZ12 replication, we tried to introduce the recombinant plasmids (pTZ122, pTZ123 and pTZ124) into $B$. subtilis by transformation. The results are summarized in Fig. 3. Neither plasmid pTZ123 nor pTZ124 could replicate in B. subtilis, whereas it was found that pTZ122, which contains pTZ12 MboI fragment A, could replicate. This shows that the functional unit of pTZ12 replication must be on the $\mathrm{MboI}$ fragment A of pTZ12 and that the TaqI site and the HpaII site must be in this region (Fig. $3)$.

\section{Molecular nature of chloramphenicol acetyl- transferase}

Figure 4 summarizes the results obtained by 


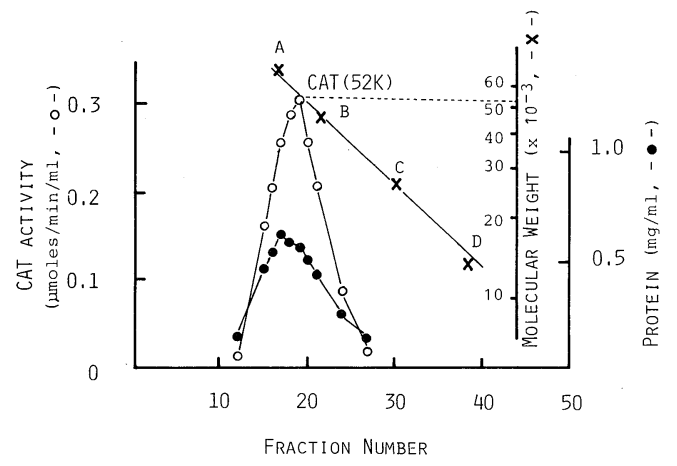

FIG. 4. Second Gel Filtration of the Cell Extracts from B. subtilis BKS2-2 on Sephadex G-100 Column.

Each $1.5 \mathrm{ml}$ fraction was assayed for CAT activity $(\bigcirc)$ and protein (O). Protein markers A; BSA (68K), B; ovalbumin (44K), C; chymotrypsinogen $(25 \mathrm{~K}), \mathrm{D}$; cytochrome $c$ $(13 \mathrm{~K})$ were eluted under the same conditions. From the elution patterns of protein markers, this CAT was calculated to be $52 \mathrm{~K}$. The peak fraction (fraction No. 19) was used as a partially-purified CAT.

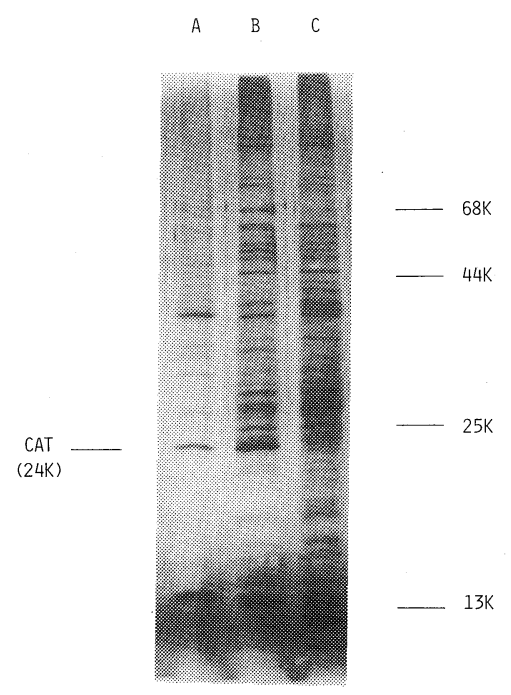

FIG. 5. SDS-Polyacrylamide Gel Electrophoresis of Cell Extracts from B. subtilis BKS2-2.

Proteins (partially-purified enzyme prepared from CPinduced culture, lane $\mathrm{A}$; crude enzyme prepared from $\mathrm{CP}$ induced culture, lane $\mathrm{B}$; crude enzyme prepared from noninduced culture, lane $C$ ) were prepared as described in the text and analyzed on an SDS- $14 \%$ polyacrylamide gel. BSA, ovalbumin, chymotrypsinogen, and cytochrome $c$ were used as molecular standards.

the second gel filtration on a Sephadex G-100 column using the partially-purified CAT which was prepared from the crude extract of CP- induced B. subtilis BKS2-2, carrying pTZ12. Protein markers were put on the same column and eluted under the same conditions. The molecular weight of the native enzyme from $B$. subtilis BKS2-2 was approximately $52 \mathrm{~K}$ by comparison of the elution pattern of protein markers. On the other hand, the crude extract was prepared from the B. subtilis BKS2-2 cells grown with or without $12.5 \mu \mathrm{g}$ of $\mathrm{CP}$ per $\mathrm{ml}$ in BHI broth. The CAT activity of the crude extract prepared from CP-induced culture was $1.61 \mu \mathrm{mol} / \mathrm{mg}$ protein $/ \mathrm{min}$ and that of the crude extract prepared from the culture without $\mathrm{CP}$ was $0.03 \mu \mathrm{mol} / \mathrm{mg}$ protein $/ \mathrm{min}$. Each two $\mu \mathrm{g}$ of proteins, partially-purified enzyme prepared from the CP-induced culture, crude enzyme from $\mathrm{CP}$-induced culture, and crude enzyme from non-induced culture, were analyzed by SDS-polyacrylamide gel electrophoresis and by Ag staining for protein. The results are shown in Fig. 5. A major protein band of partially-purified enzyme was found at the position which is approximately $24 \mathrm{~K}$ in molecular weight. The $24 \mathrm{~K}$ protein band was also found in the crude enzyme from the CPinduced culture, but the band was not found in the crude enzyme from the non-induced culture. These suggested that the $24 \mathrm{~K}$ band was a CAT subunit.

\section{DISCUSSION}

The CPr plasmid pTZ12 of B. subtilis was investigated using the in vitro recombination technique. We found that the essential region of CP resistance and replication of pTZ12 was in the $M b o \mathrm{I}$ fragment $\mathrm{A}$ of $2.0 \mathrm{~kb}$ (Fig. 3). From the mapping data of the $\mathrm{CP}^{\mathrm{r}}$ determinant and the functional unit of replication, it was thought that plasmid pTZ12 was a more useful cloning vector because this plasmid was smaller, with a high copy number, $180 \sim 200$ per chromosome. ${ }^{8)}$

CAT from $B$. subtilis carrying pTZ12 exists as native enzyme with the molecular weight of approximately $52 \mathrm{~K}$ in the crude extract, but the molecular weight of this CAT was found to be approximately $24 \mathrm{~K}$ from the result of SDS- 
polyacrylamide gel electrophoresis. The $\mathrm{CP}^{\mathrm{r}}$ determinant was mapped in the region of about 900 base pairs on pTZ12, therefore the molecular weight of this inducible CAT should theoretically be below $36 \mathrm{~K}$. This suggests that this CAT exists as a dimer of two identical subunits in the crude extract and that the molecular weight of this CAT monomer is approximately $24 \mathrm{~K}$ by SDS-polyacrylamide gel electrophoresis. The CAT gene coding the molecular weight of $24 \mathrm{~K}$ protein must contain at least 600 base pairs of DNA with another 50 to 100 base pairs alloted for the promotoroperator region, and therefore the 900 base pairs region on $\mathrm{pTZ} 12$ is enough to code for this CAT gene.

All CAT variants studied in detail are tetrameric proteins of four identical subunits, each subunit having a molecular weight in the range $23 \mathrm{~K} \sim 25 \mathrm{~K} .^{16 \sim 18)}$ The CAT of pTZ12 has a molecular weight in this range, but it is noteworthy that this CAT may be composed of two identical subunits. The studies on pTZ12 will be done in more detail to extend the knowledge of the structural and functional properties of the CAT.

\section{REFERENCES}

1) S. D. Ehrlich, Proc. Natl. Acad. Sci. U.S.A., 74, 1680
(1977).

2) M. Kono, M. Sasatsu and H. Hamashima, Microbios. Lett., 5, 55 (1978).

3) T. J. Gryczan, S. Contente and D. Dubnau, J. Bacteriol., 134, 318 (1978).

4) M. Kono, H. Hamashima, T. Aoki and M. Sasatsu, Agric. Biol. Chem., 46, 569 (1982).

5) M. Espinosa, P. Lopez, M. T. Perez-Urena and S. A. Lacks, Molec. Gen. Genet., 188, 195 (1982).

6) M. Kono, M. Sasatsu, H. Hamashima and T. Yamakawa, Microbios. Lett., 6, 67 (1978).

7) N. Noguchi, K. Shishido, T. Ando and M. Kono, Gene, 21, 105 (1983).

8) M. Kono, M. Sasatsu, T. Aoki and N. Noguchi, Agric. Biol. Chem., 48, 821 (1984).

9) T. Uozumi, T. Hoshino, K. Miwa, S. Horinouchi, T. Beppu and K. Arima, Molec. Gen. Genet., 152, 65 (1977).

10) E. S. Lennox, Virology, 1, 190 (1955).

11) T. Tanaka, M. Kuroda and K. Sakaguchi, J. Bacteriol., 129, 1487 (1977).

12) H. C. Birnboim and J. Doly, Nucleic Acids Res., 7, 1513 (1979).

13) S. Chang and S. N. Cohen, Molec. Gen. Genet., 168, 111 (1979).

14) M. Mandel and A. Higa, J. Mol. Biol., 53, 159 (1970).

15) S. Iyobe, M. Kono, K. Ohara, H. Hashimoto and S. Mitsuhashi, Antimicrob. Agents Chemother., 5, 68 (1974).

16) W. V. Shaw, Methods Enzymol., 43, 737 (1975).

17) Y. Zaidenzaig, J. E. Fitton, L. C. Packman and W. V. Shaw, Eur. J. Biochem., 100, 609 (1979).

18) W. V. Shaw, Crit. Rev. Biochem., 14, 1 (1983). 